\title{
Response of Vitis vinifera L. cv. Merlot to Low Frequency Irrigation and Partial Root Zone Drying in the Western Cape Coastal Region - Part II. Vegetative Growth, Yield and Quality
}

\author{
P.A. Myburgh \\ ARC Infruitec-Nietvoorbij ${ }^{1}$, Private Bag X5026, 7599, Stellenbosch, South Africa
}

Submitted publication: October 2010

Accepted for publication: November 2010

Key words: Subsurface irrigation, grapevine, berry mass, roots, irrigation water productivity

\begin{abstract}
The impact of five drip irrigation strategies on vegetative growth, yield and quality of Merlot/99R was compared to a non-irrigated control (T1) in the coastal region of the Western Cape province. Irrigations at pea size, véraison and post-harvest, either applied in grapevine rows (T2) or work rows (T4), tended to increase berry mass and yield compared to T1. More frequent irrigation at pea size, midway between pea size and véraison, at véraison, midway between véraison and harvest, and post-harvest, applied either in the grapevine rows (T3) or work rows (T5), increased berry mass and yield. A partial root zone drying (PRD) strategy, obtained by switching subsurface irrigation in the work rows between alternating rows at approximately 14-day intervals (T6), induced a similar trend. Under the given conditions, yield only increased when irrigation plus rainfall from bud break in September until harvest in February/March increased from ca. $200 \mathrm{~mm}$ to $400 \mathrm{~mm}$. More water did not cause any further yield increases. Although low frequency irrigation increased yields compared to $\mathbf{T} 1$, it did not affect sensorial wine quality characteristics negatively. Non-irrigated grapevines produced the smallest berries, but did not necessarily produce wine superior in quality. The PRD strategy reduced wine quality, particularly when irrigation was applied at a high frequency between switches. The latter strategy only improved irrigation water productivity when compared to conventionally irrigated grapevines that received unnecessary high volumes of water. Subsurface irrigation applied in the work rows did not affect grapevine responses compared to irrigation in the grapevine rows.
\end{abstract}

\section{INTRODUCTION}

Irrigation resources are limited in the Western Cape province, which has a Mediterranean climate, i.e. long, dry summers. Furthermore, water allocations from existing government schemes are not likely to be increased. Considering possible climate changes, the worst case scenario would be if lower rainfall reduces natural water resources and higher air temperatures increase the water requirements of vineyards. Even if climate change does not affect vineyard evapotranspiration, grape growers still need to use irrigation water more efficiently, viz. to maintain existing yields by using less water or to produce more grapes with the water available.

There are various ways in which irrigation water can be used more efficiently. Based purely on the irrigation application efficiency of different irrigation systems (Ley, 1994), converting from full surface overhead irrigation to drip irrigation could improve the water-use efficiency substantially. Similarly, full surface flood irrigation produced $1.9 \mathrm{~kg}$ grapes per $\mathrm{m}^{3}$ of irrigation water compared to $3.3 \mathrm{~kg} / \mathrm{m}^{3}$ obtained with furrow irrigation (Myburgh, 2003). Less frequent irrigation will reduce evaporation losses from the soil surface (Myburgh, 1998), and reduce vineyard evapotranspiration (Myburgh, 2003; Myburgh, 2007c; Myburgh \& Howell, 2007). Hence, if less frequent irrigation does not decrease yield and/or wine quality substantially, it could also result in the more efficient use of irrigation water. It is also possible to produce more grapes on larger trellis systems using the same amount of irrigation water (Van Zyl \& Van Huyssteen, 1980; Swanepoel et al., 1990). Furthermore, it was shown that switching irrigations between alternating work rows can sustain adequate grapevine growth and yield on a large trellis system, although approximately $36 \%$ less irrigation water is required compared to full-surface irrigation (Myburgh, 2003). Since adequate water and deep, fertile soil are prerequisites for sustaining grapevines on larger trellis systems, the latter might not be a viable option where water resources are limited. Previous studies have suggested that irrigation according to the partial root zone drying (PRD) strategy improved the water-use efficiency of vineyards substantially without reducing yield and grape quality compared to conventional drip irrigation (Dry et al., 1996; Loveys et al., 2000; Du Toit et al., 2003; Dos Santos et al., 2003; Santos et al., 2005; Bindon et al., 2008; Sadras, 2009).

The Fruit, Vine and Wine Institute of the Agricultural Research Council.

Corresponding author: MyburghP@arc.agric.za

Acknowledgements: I wish to thank the ARC, for infrastructure and other resources, Winetech, for partial funding, Netafim SA, for irrigation equipment, the Soil and Water Science staff at the ARC Infruitec-Nietvoorbij, for technical support, and Mr P. Blake, for permission to work in his vineyard. 
The irrigation requirements of vineyards in the coastal wine grape region are relatively low if the total surface is wetted, e.g. by means of portable overhead sprinklers or permanent micro-sprinkler systems. In this regard it was concluded that a single irrigation at véraison would be sufficient for Chenin blanc vineyards in the Stellenbosch area (Van Zyl \& Weber, 1981). Compared to irrigations applied at pea size berries and véraison, a third irrigation applied to alleviate grapevine water constraints during berry ripening did not have any positive effects on the yield or sensorial wine quality of Sauvignon blanc or Chenin blanc grapevines (Myburgh, 2005). Where irrigations were applied at a high frequency, i.e. only $10 \%$ plant available water (PAW) depletion was allowed between irrigations, drip irrigation had no effect on berry size, but increased sugar content and reduced the total titratable acid (TTA) in Colombar juice compared to irrigation with micro-sprinklers (Van Zyl, 1984). In contrast, drip irrigation intensified grape colour but reduced the berry size of Barlinka table grapes that were irrigated at 40\% PAW depletion (Myburgh, 1996). Since PAW is depleted to a high degree between low frequency irrigations applied over the full surface (Van Zyl \& Weber, 1981; Myburgh, 2005), there is some uncertainty regarding the grapevine yield and wine quality responses to low frequency drip irrigation strategies where, in general, smaller soil volumes are wetted compared to full surface irrigation.

The objective of this study was to determine the impact of low frequency drip irrigation and PRD on the growth, yield and quality characteristics of grapevines in a region where water resources are limited.

\section{MATERIALS AND METHODS \\ Experiment layout}

The field trial was carried out over four seasons, viz. from 2003/04 until 2006/07, in a fifteen-year-old commercial Merlot/99 Richter vineyard near Wellington in the coastal wine grape region at $33^{\circ} 38^{\prime}$ latitude. The vineyard was on a southwest-facing slope at an altitude of $132 \mathrm{~m}$. The region has a Mediterranean climate. The soil properties have been described previously (Myburgh, 2011). Based on the growing degree days (GDD) from September until March (Winkler, 1962), the specific locality is in a class $\mathrm{V}$ climatic region, which is considered to be suitable for dessert wine and brandy production (Le Roux, 1974). Selected atmospheric variables recorded during the four seasons are compared to the long-term mean values in Table 1. All weather data were obtained from the ARC Institute for Soil, Climate and Water in Pretoria. Details of the soil, irrigation system and viticultural practices were described previously by Myburgh (2011). Five irrigation strategies were compared to a non-irrigated (rain fed or dry land) control (T1). Grapevines of two treatments (T2 and T4) received three irrigations, viz. (i) when the berries reached pea size ( $3^{\text {rd }}$ week in November), (ii) at véraison ( $1^{\text {st }}$ week in January) and (iii) post-harvest (March). Over the four seasons, approximately $32 \mathrm{~mm}$ of water was required per irrigation to restore the soil water content to field capacity in the T2 and T4 plots. A further two treatments (T3 and T5) received five irrigations, viz. (i) when the berries reached pea size, (ii) midway between pea size and véraison (midDecember), (iii) at véraison, (iv) midway between véraison and harvest (end January) and (v) post-harvest. Irrigations amounted to $c a .26 \mathrm{~mm}$ each, with five irrigations being applied during the first three seasons. During the 2006/07 season, the T3 and T5 grapevines were irrigated at a high frequency, i.e. twice a week. Following an initial irrigation of $c a .20 \mathrm{~mm}$ at pea size berries, $13 \mathrm{~mm}$ of water was applied per irrigation until the post-harvest period. In the case of the T2 and T3 plots, dripper lines were installed in the grapevine rows, whereas those of T4 and T5 were installed ca. $150 \mathrm{~mm}$ below the surface in the middle of the work rows.

A PRD strategy was also included where irrigation was applied via subsurface dripper lines in the work rows (T6). Since the soil and roots had to re-settle where the subsurface irrigation lines were installed, the 2003/04 season was regarded as a preparatory phase. In this particular season, irrigation was only applied every 14 days in alternating work rows of the T6 plots. Following an initial irrigation of $c a .20 \mathrm{~mm}$ at pea size berries, $14 \mathrm{~mm}$ of water was applied per irrigation until the post-harvest period. In the 2004/05 season, irrigation was applied once a week to a set of alternating work rows to obtain a PRD effect. After approximately two to three weeks, irrigation was switched to the work rows that had been left to dry out. These cycles were repeated from pea size berries until harvest. In the case of the PRD strategy, two irrigation volumes were basically required. Small, frequent irrigations were required to maintain a relatively high soil water content in one set of alternating rows. When the irrigation was switched between the two sets of work rows, a relatively large initial irrigation was needed to restore the water content to field capacity in the set of work rows that had been left to dry out. In 2004/05, the small weekly irrigations amounted to $c a .7 \mathrm{~mm}$ and the larger initial or "refill" ones to $c a$. $19 \mathrm{~mm}$. Since weekly irrigations were inadequate to maintain relatively wet soil conditions, a set of alternating PRD work rows was irrigated twice a week in the 2005/06 and 2006/07 seasons. In this case, $7 \mathrm{~mm}$ was applied twice a week, whereas the refill irrigations amounted to $19 \mathrm{~mm}$. When the T3 and T5 grapevines were irrigated at the same frequency as the PRD ones in the 2006/07 season, the latter strategy only required $35 \%$ less water compared to T3 and T5. Due to the larger refill irrigations, it was not possible to save $50 \%$ on the irrigation water compared to $\mathrm{T} 3$ and $\mathrm{T} 5$, although only half of the work rows were irrigated at a time. All treatments were replicated four times in a randomised block design. Experimental plots comprised two rows of six grapevines each, with two buffer grapevines at each end and a buffer row on each side. Each experimental plot covered $144 \mathrm{~m}^{2}$. The qualification of grapevine water status was done according to the water constraint classes based on stem water potential (Table 2), as was proposed for the conditions of this field trial (Myburgh, 2011).

\section{Root distribution and development}

The basic structures of the root systems were determined in three replications of each treatment during October 2007. The profile wall method of Böhm (1979) was used to qualify root distribution within the constraints of the technique. A trench, $3 \mathrm{~m}$ long and $1 \mathrm{~m}$ deep, was dug across the work row between four experimental grapevines, with the long sides $100 \mathrm{~mm}$ from the grapevines. After the roots were exposed, a $100 \mathrm{~mm} \times 100$ $\mathrm{mm}$ portable wire grid was placed against the profile wall for mapping of the roots. The roots were classified according to 
their diameter (d) into four classes, namely fine $(\mathrm{d} \leq 0.5 \mathrm{~mm})$, medium $(0.5 \mathrm{~mm}<\mathrm{d} \leq 2.0 \mathrm{~mm})$, coarse $(2.0 \mathrm{~mm}<\mathrm{d} \leq 5.0 \mathrm{~mm})$ and thick $(\mathrm{d}>5.0 \mathrm{~mm})$.

\section{Vegetative growth and yield}

Vegetative growth was quantified by measuring the cane mass of the experimental grapevines in each plot at pruning in July using a hanging balance. All bunches in each plot were picked and counted using mechanical counters. The grapes were weighed to obtain the total mass per plot. Mean yield per grapevine was calculated and converted to ton per hectare. Bunch mass was determined by dividing total grape mass per plot by the number of bunches per plot. The number of bunches per grapevine was calculated by dividing the total number of bunches per plot by the number of experimental grapevines per plot. Fresh berry mass was determined in all the

TABLE 1

Mean monthly values of selected atmospheric variables measured over four seasons near Wellington compared to the long term mean (LTM).

\begin{tabular}{|c|c|c|c|c|c|c|c|}
\hline Season & September & October & November & December & January & February & March \\
\hline & \multicolumn{7}{|c|}{ Maximum temperature $\left({ }^{\circ} \mathbf{C}\right)$} \\
\hline 2003/04 & 19.8 & 24.4 & 27.2 & 27.0 & 31.2 & 31.6 & 27.5 \\
\hline $2004 / 05$ & 23.0 & 25.2 & 28.4 & 30.0 & 30.6 & 32.2 & 30.1 \\
\hline 2005/06 & 22.1 & 24.2 & 27.5 & 29.5 & 32.1 & 32.6 & 29.7 \\
\hline 2006/07 & 23.6 & 25.4 & 27.9 & 27.6 & 32.5 & 30.3 & 30.3 \\
\hline \multirow[t]{2}{*}{ LTM } & 21.2 & 24.8 & 27.1 & 29.0 & 30.6 & 31.6 & 29.8 \\
\hline & \multicolumn{7}{|c|}{ Minimum temperature $\left({ }^{\circ} \mathrm{C}\right)$} \\
\hline $2003 / 04$ & 11.2 & 14.2 & 14.1 & 15.1 & 19.1 & 19.0 & 14.7 \\
\hline $2004 / 05$ & 12.1 & 13.7 & 15.7 & 18.2 & 19.4 & 19.0 & 18.2 \\
\hline 2005/06 & 10.7 & 12.3 & 15.4 & 15.9 & 19.0 & 18.3 & 16.1 \\
\hline 2006/07 & 13.0 & 14.0 & 15.8 & 16.3 & 19.2 & 16.2 & 17.5 \\
\hline \multirow[t]{2}{*}{ LTM } & 11.3 & 13.4 & 15.1 & 16.8 & 18.1 & 19.0 & 17.0 \\
\hline & \multicolumn{7}{|c|}{ Minimum relative humidity (\%) } \\
\hline $2003 / 04$ & 51.4 & 43.5 & 35.8 & 37.6 & 33.0 & 36.0 & 32.8 \\
\hline $2004 / 05$ & 37.5 & 34.5 & 34.1 & 33.0 & 29.5 & 30.2 & 31.4 \\
\hline $2005 / 06$ & 44.9 & 33.4 & 31.8 & 26.5 & 29.3 & 32.0 & 26.5 \\
\hline $2006 / 07$ & 37.1 & 34.2 & 33.5 & 34.1 & 30.1 & 33.4 & 29.2 \\
\hline \multirow[t]{2}{*}{ LTM } & 47.7 & 39.8 & 35.9 & 33.8 & 29.0 & 34.0 & 34.1 \\
\hline & \multicolumn{7}{|c|}{ Rainfall (mm) } \\
\hline $2003 / 04$ & 63 & 21 & 0 & 13 & 17 & 0 & 10 \\
\hline $2004 / 05$ & 33 & 105 & 11 & 4 & 68 & 4 & 6 \\
\hline $2005 / 06$ & 47 & 31 & 45 & 0 & 0 & 15 & 11 \\
\hline $2006 / 07$ & 46 & 36 & 52 & 21 & 0 & 23 & 34 \\
\hline LTM & 47 & 26 & 23 & 20 & 15 & 13 & 26 \\
\hline
\end{tabular}

TABLE 2

Stem water potential $\left(\Psi_{\mathrm{S}}\right)$ thresholds to classify water stress in Merlot/99R near Wellington, as proposed by Myburgh (2011).

\begin{tabular}{ccc}
\hline Class & Water constraints & Stem water potential thresholds (MPa) \\
\hline I & None & $\Psi_{\mathrm{S}} \geq-0.4$ \\
II & Mild & $-0.4>\Psi_{\mathrm{S}} \geq-1.0$ \\
III & Moderate & $-1.0>\Psi_{\mathrm{S}} \geq-1.4$ \\
IV & Strong & $-1.4>\Psi_{\mathrm{S}} \geq-1.6$ \\
V & Severe & $\Psi_{\mathrm{S}}<-1.6$ \\
\hline
\end{tabular}


plots at harvest. Berry samples were obtained by picking 20 berries along the longitudinal axis from each of ten bunches per plot. Berries were removed by cutting through the pedicel as close as possible to the berry using a small pair of scissors. Irrigation water productivity (IWP) was calculated by dividing the yield $(\mathrm{kg})$ per hectare by the volume of irrigation water $\left(\mathrm{m}^{3}\right)$ applied per hectare, as reported by Myburgh (2011).

\section{Juice and wine characteristics}

The objective was to harvest grapes when the sugar content reached a target of $25^{\circ} \mathrm{B}$. Due to logistical constraints, this was not always possible. The total soluble solids (TSS), $\mathrm{pH}$ and TTA in the juice were determined according to the standard procedures of the Infruitec-Nietvoorbij Institute of the Agricultural Research Council (ARC) near Stellenbosch. The grapevines were not expected to be in balance with the irrigation treatments during the first season, particularly those for which subsurface irrigation lines had been installed in the work row. Consequently, the 2003/04 season was regarded as a pilot phase, and grapes of the four replications were pooled in a $40 \mathrm{~kg}$ sample for winemaking. As a result, sensorial wine quality characteristics could not be compared statistically in 2003/04. In the following three seasons, wines were made from each of three replications of all treatments. Forty kilograms of grapes were picked from each plot and micro-vinified at the research winery of ARC Infruitec-Nietvoorbij. After the grapes were crushed, $50 \mathrm{mg} / \mathrm{kg} \mathrm{SO}_{2}$ was added. Skin contact was allowed for at least one hour before the crushed grapes were inoculated with a commercial wine yeast (VIN 13, Anchor Biotechnologies) at a concentration of $30 \mathrm{~g} / \mathrm{hL}$. Fifty $\mathrm{g} / \mathrm{hL}$ diammonium phosphate (DAP) was then added. Fermentation was conducted on the skins at $25^{\circ} \mathrm{C}$ and the cap was punched down three times a day. The must was fermented down to between $0^{\circ} \mathrm{B}$ and $5^{\circ} \mathrm{B}$. Following this, the skins were separated and pressed at $c a$. $0.2 \mathrm{MPa}$. The pressed wine was added to the free run-off wine and fermented at $25^{\circ} \mathrm{C}$ until dry. As soon as the fermentation was completed, the wine was racked, the $\mathrm{SO}_{2}$ was adjusted to a total of $85 \mathrm{mg} / \mathrm{L}$ (in accordance with the analysis) and the wine was cold stabilised at $0^{\circ} \mathrm{C}$ for at least two weeks. After cold stabilisation, the wine was filtered by using sterile mats (K900 and EK) as well as a $0.45 \mu \mathrm{m}$ membrane, and bottled in nitrogen-filled bottles at room temperature. The total $\mathrm{SO}_{2}$ was adapted during bottling to ensure that it was not less than $85 \mathrm{mg} / \mathrm{L}$. The bottled wines were stored at $14^{\circ} \mathrm{C}$ until they were evaluated. The wines were subjected to sensorial evaluation by a panel of at least 12 experienced wine tasters during the August following the harvest. The primary sensorial wine characteristics were colour, flavour, taste and overall wine quality. The flavour characteristics consisted of (i) fresh vegetative aroma, viz. asparagus, green bean, green pepper, fresh cut grass, olive oil, minty, and herbaceous (ii) berry aroma, viz. blackberry, raspberry, strawberry and black currant (iii) spicy aroma, viz. black pepper, cloves, liquorice, and aniseed and (iv) dried-fruit aroma, viz. strawberry jam, prune, peach, fig and raisin. The taste characteristics were acidity, fullness (body) and astringency. Wine characteristics were scored on an un-scaled line that was $100 \mathrm{~mm}$ long.

\section{Statistical analysis}

The data were subjected to an analysis of variance. Least significant difference (LSD) values were calculated to facilitate comparison between the treatment means. Means that differed at $p \leq 0.05$ were considered to be significantly different. Statgraphics ${ }^{\circledR}$ was used to fit linear regression models.

\section{RESULTS AND DISCUSSION}

\section{Root distribution and development}

Considering all the treatments, the total number of roots in each of the $300 \mathrm{~mm}$ depth increments over the $900 \mathrm{~mm}$ root depth amounted to $38 \pm 7 \%, 30 \pm 4 \%$ and $32 \pm 6 \%$ respectively. The root systems consisted primarily of fine roots (data not shown). This indicated that efficient soil preparation allowed the development of extensive root systems, particularly into the subsoil. Although there was some variability between the replications within a specific irrigation strategy, the root structures showed consistent trends. The different irrigation strategies did not increase root density along the grapevine rows and in wheel tracks in comparison to the non-irrigated control (Fig. 1). In contrast, root densities were higher compared to the control (T1) where low frequency irrigations and the PRD strategy were applied in the middle of the work rows. The higher root densities occurred primarily in the topsoil around the dripper lines (data not shown). This suggests that root pruning, which occurred where furrows were made to install the subsurface dripper lines in the work rows, stimulated the development of new roots (Van Zyl \& Van Huyssteen, 1987).

The fact that the highest irrigation frequency (T6) did not result in the highest root density is in agreement with earlier findings (Van Zyl, 1988; Myburgh, 1996). The higher root densities in the low frequency irrigated work rows (T4 and T5) contributed to higher root densities in the entire profile compared to the non-irrigated control (Fig. 2). However, these results did not rule out the possibility that fine roots in particular could have degenerated under the non-irrigated conditions, where the soil water content was almost depleted to permanent wilting point (Myburgh, 2011). The root densities throughout the entire profile, i.e. to a depth of $0.9 \mathrm{~m}$, of the low frequency irrigated grapevines (Fig. 2) were slightly higher than 179 roots $/ \mathrm{m}^{2}$ for Chenin blanc/99R in a red, sandy Hutton soil (Southey \& Archer, 1988), and 160 roots $/ \mathrm{m}^{2}$ was reported for Pinot noir/99R in a sandy loam Glenrosa soil (Hunter, 1998) at comparable plant spacings. However, profile root densities were substantially lower than the 400 roots $/ \mathrm{m}^{2}$ of Sultanina/143B Mgt in a sandy loam alluvial soil (Myburgh, 2007a).

\section{Vegetative growth}

Over the four seasons, the cane mass of all the treatments (Table 3) tended to be slightly less than the $1.9 \mathrm{t} / \mathrm{ha}$ and $2.4 \mathrm{t} / \mathrm{ha}$ reported for Merlot/110R in "dry" and "wet" plots respectively, in an Oakleaf soil near Stellenbosch (Boshoff, 2010). Cane mass was also substantially lower compared to the $c a .4 \mathrm{t} /$ ha reported for Merlot/Ramsey in fertile, alluvial soil near Ashton (Lategan \& Howell, 2010a). The higher cane mass probably resulted from the more vigour-inducing rootstock. In the 2005/06 season, lower minimum humidity and slightly higher wind speeds during November and December (Table 1) probably contributed to the lower vegetative growth compared to the other seasons (Table 3 ).

According to Myburgh (2011), the non-irrigated grapevines 


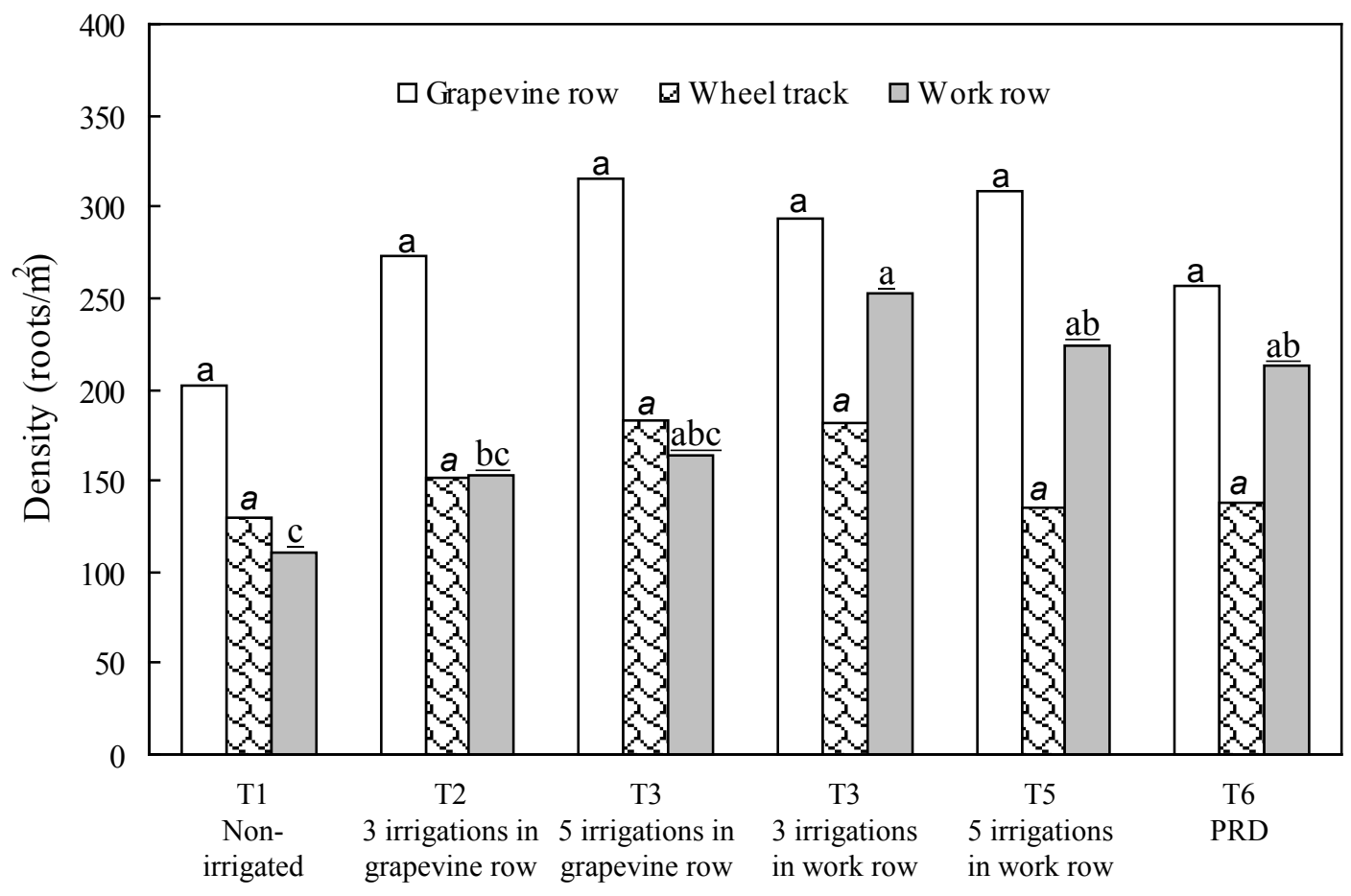

FIGURE 1

Effect of no irrigation, low frequency drip irrigation and position of irrigation lines, as well as partial root zone drying (PRD), on the root density of Merlot/99R near Wellington. Columns representing the same position that are designated by the same letter do not differ significantly $(p \leq 0.05)$.

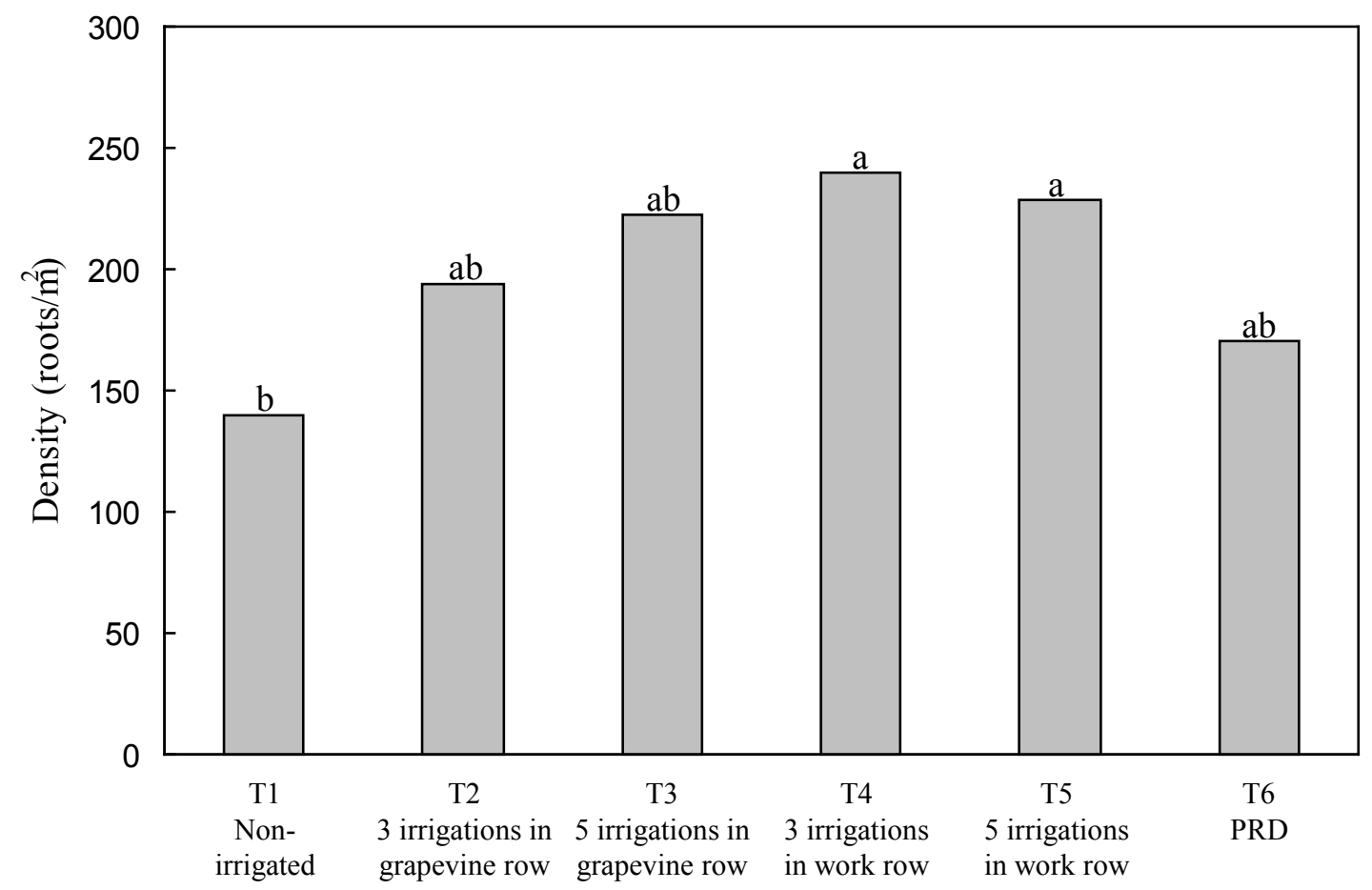

FIGURE 2

Effect of no irrigation, low frequency drip irrigation and partial root zone drying (PRD), as well as position of irrigation lines, on the root density at three positions. Statistical comparison of means was carried out per position. Columns designated by the same letter within a position do not differ significantly $(p \leq 0.05)$. 
(T1), as well as those that received three irrigations (T2 and T4), generally experienced strong to severe water constraints (Table 2). During the 2003/04 season, all the irrigation strategies increased cane mass compared to the non-irrigated conditions (Table 3). The lack of differences in growth amongst the irrigated grapevines was probably because they had not fully adapted to a specific irrigation strategy in the first year. In the following three seasons, grapevines that received three irrigations (T2) in the grapevine row did not show stronger vegetative growth compared to the non-irrigated ones, with the exception of T4 grapevines in the 2006/07 season (Table 3). This was in agreement with the comparable water status in the T1, T2 and T4 grapevines (Myburgh, 2011). The position of the dripper lines did not have any effect on vegetative growth in the first three seasons, but in the 2006/07 season three irrigations in the work rows (T4) induced slightly stronger growth vigour compared to three irrigations applied in the grapevine rows (Table 3). This suggested that the higher root density in the work row (Fig. 1) only reflected in stronger growth after four seasons (Table 3). The mild to moderate water constraints (Table 2) in grapevines that received five irrigations caused stronger vegetative growth compared to the non-irrigated ones and those that received only three irrigations (Table 3). Where irrigations were applied more frequently, subsurface irrigation in the work rows (T3) also had no effect on vegetative growth compared to irrigation in the grapevine rows (T5). The higher root densities where irrigations were applied in the work rows (Fig. 1) did not reflect positively in the vegetative growth compared to less frequent irrigation (Table 3). The higher water availability in the case of the T5 grapevines in comparison to the T4 grapevines probably dominated the effect of more roots in the work rows (Fig. 1). Similar to more frequent irrigation, mild to moderate water constraints (Table 2) in the grapevines irrigated according to the PRD strategy induced stronger vegetative growth than in the non-irrigated ones and those that received only three irrigations (Table 3 ).

During the 2003/04 season, the T6 grapevines were irrigated more frequently, but received approximately the same volume of water as the T3 and T5 ones that were irrigated five times (Myburgh, 2011). Since irrigation in alternating work rows (T6) did not reduce vegetative growth compared to T3 and T5 (Table 3), it is suggested that the total volume of water dominated the vegetative growth response. However, in the 2004/05 season, when the PRD grapevines received 40\% more water than those that were irrigated five times (Myburgh, 2011), it did not reflect in stronger vegetative growth (Table 3 ). This suggests that growth was suppressed by the PRD effect via the production of abscisic acid (ABA) in the roots (Du Toit et al., 2003 and references therein). Similarly, the PRD strategy did not increase growth compared to the T3 and T5 grapevines (Table 3), although they received $87 \%$ more water when the irrigation frequency was increased in the 2005/06 season (Myburgh, 2011). These results confirm a strong PRD effect on vegetative growth where the irrigation was switched between alternating work rows. In some previous studies, the PRD effect was obtained by switching the irrigation between parts of the root zone in the grapevine rows (Dry et al., 1996; Marsal et al., 2008). Although the T3 and T5 grapevines received substantially more water when their irrigation frequency was increased to the same level as the PRD ones in the 2006/07 season (Myburgh, 2011), they still showed the same growth vigour as the PRD ones. This suggests that the T3 and T5 grapevines were probably close to their maximum growth potential under the given conditions in this particular season.

\section{Yield and its components}

Except where the T3 and T5 grapevines were irrigated two times per week in the 2006/07 season, berry mass obtained under non-irrigated conditions and low frequency irrigation (Table 3) was smaller than the $c a .1 .4 \mathrm{~g} /$ berry for drip-irrigated Merlot/Ramsey in fertile, alluvial soil in the Breede River Valley (Lategan \& Howell, 2010b). Three irrigations increased the berry mass in comparison to non-irrigated conditions in the 2003/04 and 2005/06 seasons (Table 3). A similar trend occurred in the other seasons. Since no differences in water constraints occurred when measured at véraison and prior to harvest (Myburgh, 2011), the cumulative effect of wetter soil conditions between irrigations probably increased berry size compared to non-irrigated conditions. Mild to moderate water constraints (Table 2) induced by five irrigations and the PRD strategy consistently produced bigger berries compared to the more constrained non-irrigated ones. In the 2005/06 and 2006/07 seasons, five irrigations (T3 and T5) also increased berry size in comparison to three irrigations (T2 and T4). With the exception of the 2003/04 season, mild to moderate water constraints induced by the PRD strategy also produced bigger berries than T2 and T4. In the 2005/06, season the moderately constrained PRD grapevines produced bigger berries compared to all the other strategies which, according to Myburgh (2011), induced strong water constraints. However, in 2006/07, when increased irrigation frequency and volume induced mild water constraints in the T3 and T5 grapevines, the berries were bigger when compared to the moderately constrained PRD ones. Berry mass was also higher where the grapevines of the control strategy received double the volume of irrigation as the PRD ones (Du Toit et al., 2003; Bindon et al., 2008). In other field experiments in which control and PRD grapevines received comparable irrigation volumes, there was no difference in berry mass (Du Toit et al., 2003; De la Hera et al., 2007, Lategan \& Howell, 2010b). The foregoing suggest that berry mass was strongly influenced by the volume of irrigation water applied over the growing season.

Over the four seasons (Table 3), yields obtained under non-irrigated conditions were comparable to the $7.8 \mathrm{t} / \mathrm{ha}$ and $9.6 \mathrm{t} / \mathrm{ha}$ reported for Merlot/110R in "dry" and "wet" plots respectively in an Oakleaf soil near Stellenbosch (Boshoff, 2010). In general, yields were substantially lower compared to the $c a .20 \mathrm{t} /$ ha for Merlot/Ramsey in fertile, alluvial soil near Ashton (Lategan \& Howell, 2010b). Seasonal yield fluctuation was probably caused by variation in bunches per grapevine or berries per bunch (Table 4). Differences in berry size induced by the different irrigation strategies reflected clearly in the bunch mass (Table 3), but the relationship depended on the seasonal variation in the number of berries per bunch (Fig. 3A). Similarly, yield variation was closely related to the differences in bunch mass, but this relationship was also influenced by seasonal variation (Fig. 3B). Seasonal variation in grapevine fertility, which might explain this, was beyond the scope of the study. Due to the positive effect of increased irrigation volumes on berry size, yield generally increased as the irrigation plus 
TABLE 3

Effects of irrigation strategies, including partial root zone drying (PRD), on cane mass at pruning, yield components and irrigation water-use efficiency (IWP) of Merlot/99R in a Glenrosa soil near Wellington over four seasons.

\begin{tabular}{|c|c|c|c|c|c|c|}
\hline \multirow[b]{2}{*}{ Season } & T1 - Non-irrigated & \multirow{2}{*}{$\begin{array}{c}\text { T2 - Three } \\
\text { irrigations in } \\
\text { grapevine row }{ }^{(1)}\end{array}$} & \multirow{2}{*}{$\begin{array}{c}\text { T3 - Five } \\
\text { irrigations in } \\
\text { grapevine row }\end{array}$} & \multirow{2}{*}{$\begin{array}{l}\text { T4- Three } \\
\text { irrigations in } \\
\text { work row }^{(1)}\end{array}$} & \multirow{2}{*}{$\begin{array}{c}\text { T5 - Five } \\
\text { irrigations in } \\
\text { work row }{ }^{(2)}\end{array}$} & \multirow[t]{2}{*}{ T6 - PRD } \\
\hline & & & & & & \\
\hline & \multicolumn{6}{|c|}{ Cane mass (t/ha) } \\
\hline $2003 / 04$ & $1.4 \mathrm{~b}^{(3)}$ & $1.6 \mathrm{a}$ & $1.6 \mathrm{a}$ & $1.7 \mathrm{a}$ & $1.7 \mathrm{a}$ & $1.6 \mathrm{a}^{(4)}$ \\
\hline $2004 / 05$ & $1.2 \mathrm{~d}$ & $1.3 \mathrm{~cd}$ & $1.7 \mathrm{a}$ & $1.4 \mathrm{bc}$ & $1.6 \mathrm{a}$ & $1.6 \mathrm{a}$ \\
\hline $2005 / 06$ & $0.9 \mathrm{c}$ & $1.0 \mathrm{c}$ & $1.3 \mathrm{a}$ & $1.1 \mathrm{bc}$ & $1.2 \mathrm{ab}$ & $1.4 \mathrm{a}$ \\
\hline \multirow[t]{2}{*}{$2006 / 07$} & $1.3 \mathrm{c}$ & $1.4 \mathrm{c}$ & $1.9 \mathrm{a}^{(5)}$ & $1.6 \mathrm{~b}$ & $1.8 \mathrm{ab}^{(5)}$ & $1.9 \mathrm{a}$ \\
\hline & \multicolumn{6}{|c|}{ Berry mass (g) } \\
\hline $2003 / 04$ & $0.85 \mathrm{~d}$ & $1.02 \mathrm{bc}$ & $1.08 \mathrm{a}$ & $0.97 \mathrm{c}$ & $0.99 \mathrm{c}$ & $1.05 \mathrm{ab}^{(4)}$ \\
\hline $2004 / 05$ & $0.95 \mathrm{c}$ & $1.11 \mathrm{bc}$ & $1.18 \mathrm{ab}$ & $1.08 \mathrm{bc}$ & $1.16 \mathrm{ab}$ & $1.28 \mathrm{a}$ \\
\hline $2005 / 06$ & $0.97 \mathrm{~d}$ & $1.14 \mathrm{c}$ & $1.25 \mathrm{~b}$ & $1.16 \mathrm{c}$ & $1.22 \mathrm{~b}$ & $1.43 \mathrm{a}$ \\
\hline \multirow[t]{2}{*}{$2006 / 07$} & $1.08 \mathrm{c}$ & $1.13 \mathrm{c}$ & $1.51 \mathrm{a}^{(5)}$ & $1.15 \mathrm{c}$ & $1.53 \mathrm{a}^{(5)}$ & $1.43 \mathrm{~b}$ \\
\hline & \multicolumn{6}{|c|}{ Bunch mass (g) } \\
\hline $2003 / 04$ & $78.8 \mathrm{c}$ & $82.1 \mathrm{bc}$ & $92.7 \mathrm{ab}$ & $83.5 \mathrm{bc}$ & $88.6 \mathrm{abc}$ & $95.6 \mathrm{a}^{(4)}$ \\
\hline $2004 / 05$ & $70.5 \mathrm{~d}$ & $91.2 \mathrm{~cd}$ & $103.7 \mathrm{ab}$ & $85.9 \mathrm{~d}$ & $97.0 \mathrm{bc}$ & $109.9 \mathrm{a}$ \\
\hline $2005 / 06$ & $75.7 \mathrm{~d}$ & $94.3 \mathrm{bc}$ & $106.4 \mathrm{ab}$ & $87.2 \mathrm{~cd}$ & $109.6 \mathrm{ab}$ & $122.1 \mathrm{a}$ \\
\hline \multirow[t]{2}{*}{$2006 / 07$} & $94.6 \mathrm{c}$ & $126.3 \mathrm{~b}$ & $183.8 \mathrm{a}^{(5)}$ & $133.3 \mathrm{~b}$ & $179.0 \mathrm{a}^{(5)}$ & $188.8 \mathrm{a}$ \\
\hline & \multicolumn{6}{|c|}{ Yield (t/ha) } \\
\hline $2003 / 04$ & $7.6 \mathrm{~b}$ & $8.8 \mathrm{ab}$ & $9.9 \mathrm{a}$ & $8.5 \mathrm{ab}$ & $9.4 \mathrm{a}$ & $9.9 \mathrm{a}^{(4)}$ \\
\hline $2004 / 05$ & $9.3 \mathrm{c}$ & $12.2 \mathrm{~b}$ & $15.1 \mathrm{a}$ & $12.5 \mathrm{~b}$ & $13.7 \mathrm{ab}$ & $15.1 \mathrm{a}$ \\
\hline $2005 / 06$ & $7.7 \mathrm{c}$ & $8.1 \mathrm{c}$ & $10.1 \mathrm{~b}$ & $8.7 \mathrm{bc}$ & $10.0 \mathrm{~b}$ & $12.2 \mathrm{a}$ \\
\hline \multirow[t]{2}{*}{$2006 / 07$} & $7.5 \mathrm{c}$ & $10.6 \mathrm{~b}$ & $17.1 \mathrm{a}^{(5)}$ & $11.3 \mathrm{~b}$ & $16.8 \mathrm{a}^{(5)}$ & $17.1 \mathrm{a}$ \\
\hline & \multicolumn{6}{|c|}{$\operatorname{IWP}\left(\mathrm{kg} / \mathrm{m}^{3}\right)$} \\
\hline $2003 / 04$ & - & $9.5 \mathrm{a}$ & $8.3 \mathrm{ab}$ & $9.2 \mathrm{ab}$ & $7.9 \mathrm{~b}$ & $7.9 b^{(4)}$ \\
\hline $2004 / 05$ & - & $11.8 \mathrm{ab}$ & $11.6 \mathrm{ab}$ & $12.1 \mathrm{a}$ & $10.6 \mathrm{~b}$ & $8.4 \mathrm{c}$ \\
\hline $2005 / 06$ & - & $9.1 \mathrm{ab}$ & $7.6 \mathrm{~b}$ & $9.7 \mathrm{a}$ & $7.5 \mathrm{~b}$ & $4.9 \mathrm{c}$ \\
\hline $2006 / 07^{(4)}$ & - & $11.0 \mathrm{a}$ & $4.7 c^{(5)}$ & $11.8 \mathrm{a}$ & $4.6 \mathrm{c}^{(5)}$ & $7.2 \mathrm{~b}$ \\
\hline
\end{tabular}

(1) Irrigations at pea size, véraison and post-harvest.

${ }^{(2)}$ Irrigations at pea size, mid-December, véraison, end January and post-harvest.

(3) Values followed by the same letter within a row do not differ significantly $(\mathrm{p} \leq 0.05)$.

(4) In 2003/04, the T6 grapevines received only low frequency irrigation in alternating work rows.

(5) In 2006/07, the T3 and T5 grapevines were irrigated at the same frequency as the PRD ones.

TABLE 4

Seasonal variation in mean number of berries per bunch and bunches per grapevine of Merlot/99R in a Glenrosa soil near Wellington. Values in brackets indicated standard deviation.

\begin{tabular}{ccccc}
\hline \multirow{2}{*}{ Yield component } & \multicolumn{3}{c}{ Season } \\
\cline { 2 - 5 } & $\mathbf{2 0 0 3 / 0 4}$ & $\mathbf{2 0 0 4 / 0 5}$ & $\mathbf{2 0 0 5 / 0 6}$ & $\mathbf{2 0 0 6 / 0 7}$ \\
\hline Berries per bunch & $88 \pm 4.4$ & $82 \pm 4.9$ & $81 \pm 5.3$ & $113 \pm 4.6$ \\
Bunches per grapevine & $31 \pm 1.4$ & $43 \pm 2.1$ & $29 \pm 1.8$ & $29 \pm 2.7$ \\
\hline
\end{tabular}

rainfall from September until February increased (Fig. 4). However, this increase was non-linear. Under the given conditions, irrigation plus rainfall less than ca. $200 \mathrm{~mm}$ had almost no effect on yield. Yield only increased linearly between ca. $200 \mathrm{~mm}$ and ca. $400 \mathrm{~mm}$. More irrigation water did not seem to cause any further increase in yield. There is no explanation for the relatively low yield of the PRD grapevines in the 2005/06 season. Subsurface drip irrigation in the work rows did not have any effect on yield compared to irrigation in the grapevine rows in any of the seasons (Table 3). Slightly higher root densities caused by irrigation in the work rows (Fig. 1) were insufficient to reflect in higher yields in comparison to irrigation applied in the grapevine rows. Subsurface drip irrigation also held no advantage over above-ground drip regarding the growth and 
yield of Sultanina/143B Mgt grapevines (Myburgh, 2007b). These results suggest that the application of the PRD strategy in alternating work rows could not have introduced any artefacts in terms of grapevine response. Furthermore, it was shown that a substantial percentage of subsurface drippers can become clogged by root penetration within a few years when compared to above-ground drippers (Myburgh, 2007a). This risk reduces the economic viability of sub-surface drip irrigation.

Expressing the irrigation water productivity merely as the ratio between fresh mass of grapes produced and a unit of irrigation water can be misleading. In reality, the objective should be either to produce more grapes using the same volume of irrigation water, or to produce the same yields using less water under a given set of climatic, soil and viticultural conditions. Since yields did not differ in the 2003/04 season (Table 3), three irrigations in the grapevine row increased IWP compared to five irrigations in the work rows (T5) and the PRD strategy (T6) when more irrigation was applied (Myburgh, 2011). Likewise, three irrigations in the work rows improved IWP compared to T5 and T6 in the 2004/05 season. Although
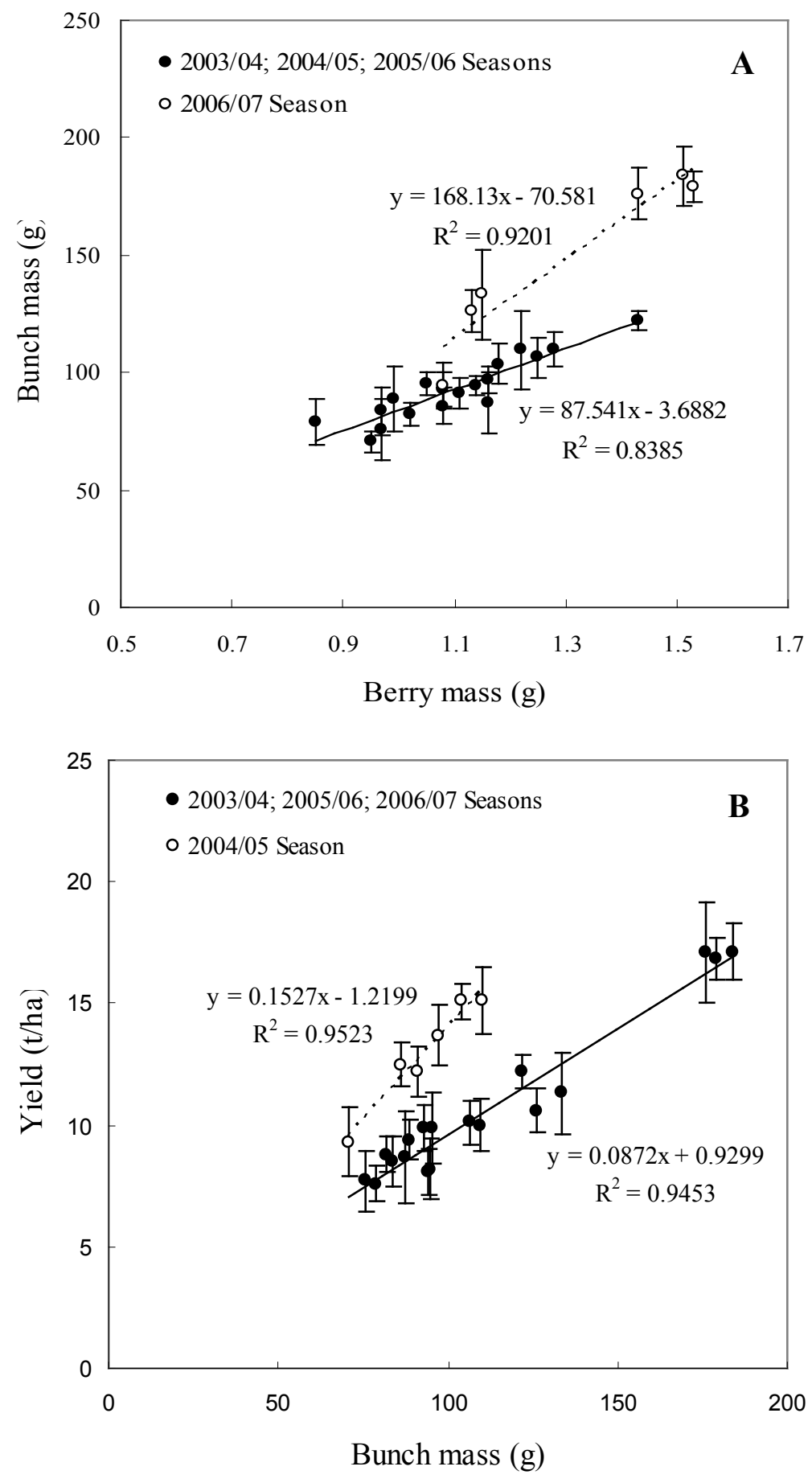

FIGURE 3

Relationship between (A) bunch mass and berry mass as well as (B) yield and bunch mass of Merlot/99R over four seasons near Wellington. Vertical bars indicate standard deviation $(n=4)$. 


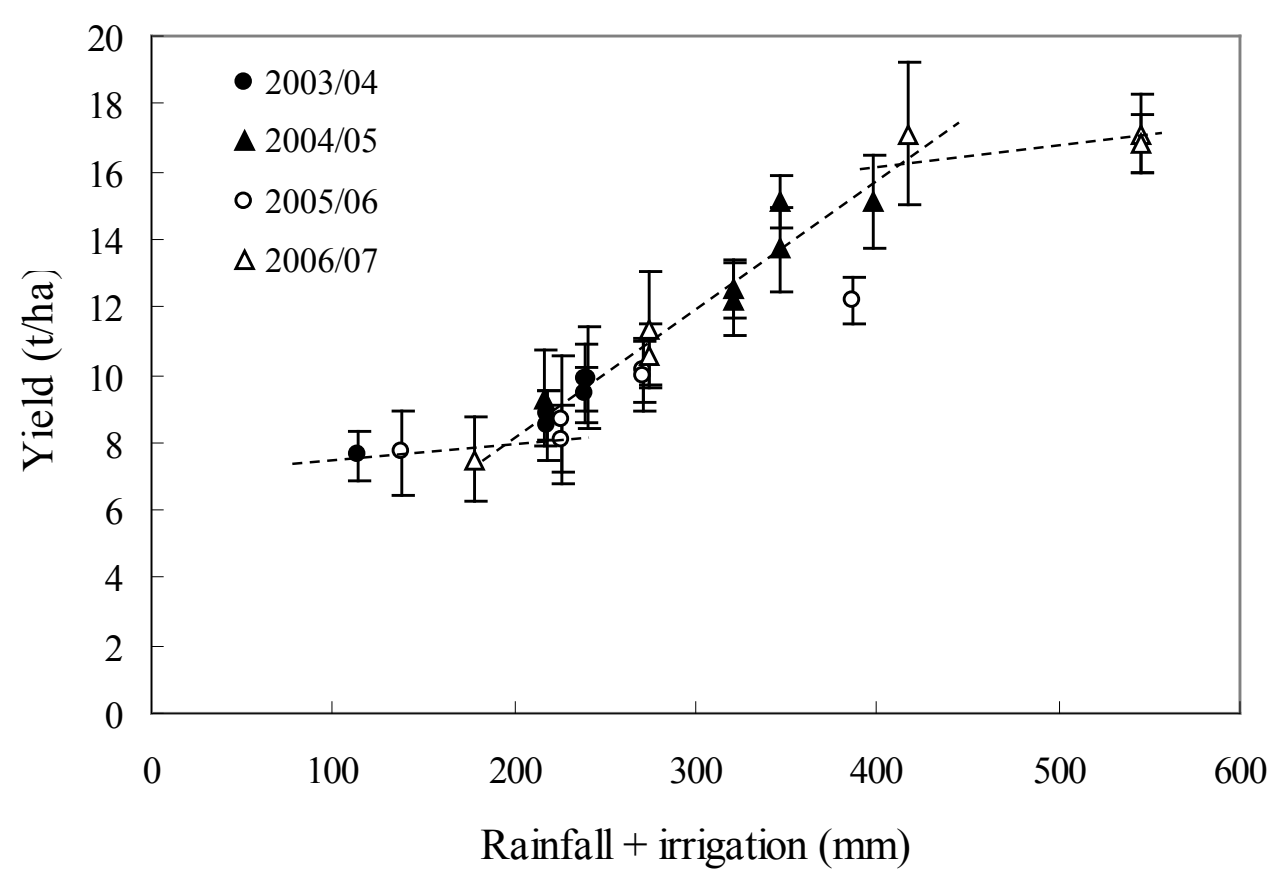

FIGURE 4

Relationship between Merlot/99R yield and rainfall from September until February plus irrigation applied, as measured over four seasons near Wellington. Vertical bars indicate standard deviation. Dashed trend lines were fitted by eye.

the ratio of fresh mass to irrigation volume obtained with low frequency irrigations was higher when compared to the PRD strategy in the 2005/06 season, the PRD strategy produced higher yields, which implies that low frequency irrigation did not improve IWP according to the abovementioned criteria. Similarly, the higher ratios obtained with only three irrigations in the 2006/07 season could not be regarded as more efficient irrigation water use compared to the other strategies. On the other hand, the PRD strategy improved the IWP compared to the T3 and T5 grapevines, which produced comparable yields in this particular season. The fact that the higher irrigation frequency did not increase the yield of the T3 and T5 grapevines concomitantly (Table 4), suggests that these grapevines were over-irrigated, whereas the PRD grapevines probably received just enough irrigation to enable optimum yield under the given conditions. Previous studies also showed that the PRD strategy improved IWP when compared to grapevines that were irrigated at a relatively high intensity, e.g. using two dripper lines per grapevine row to irrigate the control (Dry et al., 1996; Marsal et al., 2008) or irrigating a "full irrigation" strategy at $100 \%$ of potential evaporation (Dos Santos et al., 2003; Santos et al., 2005). By analysing results generated by studies where the PRD strategy was compared to controls that received substantially more water, it was concluded that comparably higher IWP could be achieved with deficit irrigation, without the complexity and additional cost of PRD (Sadras, 2009).

\section{Juice characteristics}

The different irrigation strategies did not have strong effects on sugar accumulation when compared to non-irrigated conditions during the first three seasons. Consequently, the grapes of all the treatments were harvested on the same day in these seasons.
In the 2003/04 season, when, according to Myburgh (2011), all the grapevines experienced moderate to strong water constraints (Table 2), non-irrigated conditions (T1) only tended to delay sugar accumulation in comparison to irrigated grapevines (Table 5). In the 2004/05 season, mild water constraints in the PRD grapevines slightly reduced sugar content compared to grapevines in which three irrigations induced moderate water constraints (T2 and T4). However, PRD was not shown to have any effect on juice sugar content when it was compared to intensively irrigated control treatments in previous studies (Dry et al., 1996; Loveys et al., 2000; Dos Santos et al., 2003; Santos et al., 2005; Bindon et al., 2008). Drier (T1) as well as slightly wetter soil conditions (T3 and T5) only tended to delay sugar accumulation. In the 2005/06 season, strong to severe water constraints (Table 2) in the non-irrigated and low frequency irrigated grapevines increased sugar content compared to the moderately constrained PRD grapevines (Table 5). Mild water constraints in grapevines that were irrigated at a high frequency (T3 and T5), as well as moderate water constraints in the PRD grapevines, reduced the rate of sugar accumulation considerably when compared to the T1, T2 and T4 vines, which were subjected to severe water constraints during the 2006/07 season (Myburgh, 2011). On 2 February 2007, i.e. when the grapes of the driest irrigation strategies (T1, T2 and T4) were harvested in that particular season, the sugar content was still $c a .22^{\circ} \mathrm{B}$ in the grapes of the wetter strategies (T3, $\mathrm{T} 5$ and T6). In the period that followed, sugar accumulation remained slow when grapevines experienced mild to moderate water constraints (Table 5). Grapes of the PRD treatment were harvested on 14 February 2007, whereas T3 and T5 grapes were only harvested on $8 \mathrm{March}$, despite a cut-back in irrigation. Due to the visual physical deterioration, particularly after untimely 
rainfall (Table 1), the grapes of the wetter treatments had to be harvested before their sugar contents reached the target value of $25^{\circ} \mathrm{B}$. The combined effects of high yields and mild to moderate water constraints (Myburgh, 2011) most likely contributed to the slow sugar accumulation. The relatively low night temperatures during February compared to the other seasons (Table 1) probably also had a negative impact on sugar accumulation. Irrigation applied in the work rows had no effect on sugar accumulation when compared to irrigation in the grapevine rows during any of the seasons (Table 5).

During the 2003/2004 season, moderate water constraints in the PRD grapevines tended to reduce juice TTA compared to non-irrigated conditions and low frequency irrigation (Table 5). However, mild water constraints in the PRD grapevines in the 2004/05 season produced significantly lower TTA compared to all the other strategies. The PRD strategy also lowered TTA

TABLE 5

Effects of irrigation strategies, including partial root zone drying (PRD), on juice and sensorial wine quality characteristics of Merlot/99R in a Glenrosa soil near Wellington over four seasons.

\begin{tabular}{|c|c|c|c|c|c|c|}
\hline Season & T1 - Non-irrigated & $\begin{array}{c}\text { T2 - Three } \\
\text { irrigations in } \\
\text { grapevine row }^{(1)}\end{array}$ & $\begin{array}{c}\text { T3 - Five } \\
\text { irrigations in } \\
\text { grapevine row }\end{array}$ & $\begin{array}{c}\text { T4 - Three } \\
\text { irrigations in } \\
\text { work row }^{(1)}\end{array}$ & $\begin{array}{c}\text { T5 - Five } \\
\text { irrigations in } \\
\text { work row }^{(2)}\end{array}$ & T6 - PRD \\
\hline & \multicolumn{6}{|c|}{ Total soluble solids $\left({ }^{\circ} \mathrm{B}\right)$} \\
\hline $2003 / 04$ & $25.3 \mathrm{a}^{(3)}$ & $26.7 \mathrm{a}$ & $25.7 \mathrm{a}$ & $26.7 \mathrm{a}$ & $25.7 \mathrm{a}$ & $26.2 \mathrm{a}^{(4)}$ \\
\hline $2004 / 05$ & $24.7 \mathrm{ab}$ & $25.3 \mathrm{a}$ & $24.9 \mathrm{ab}$ & $25.3 \mathrm{a}$ & $24.7 \mathrm{ab}$ & $24.3 \mathrm{~b}$ \\
\hline $2005 / 06$ & $25.7 \mathrm{a}$ & $26.1 \mathrm{a}$ & $25.8 \mathrm{a}$ & $26.3 \mathrm{a}$ & $25.5 \mathrm{a}$ & $24.1 \mathrm{~b}$ \\
\hline \multirow[t]{2}{*}{$2006 / 07$} & $24.9 \mathrm{a}$ & $26.1 \mathrm{a}$ & $23.3 c^{(5)}$ & $25.9 \mathrm{a}$ & $23.5 \mathrm{c}^{(5)}$ & $23.2 \mathrm{c}$ \\
\hline & \multicolumn{6}{|c|}{ Total titratable acidity $(\mathrm{g} / \mathrm{L})$} \\
\hline $2003 / 04$ & $5.4 \mathrm{a}$ & $5.3 \mathrm{a}$ & $5.1 \mathrm{a}$ & $5.5 \mathrm{a}$ & $5.1 \mathrm{a}$ & $4.8 \mathrm{a}^{(4)}$ \\
\hline $2004 / 05$ & $6.4 \mathrm{a}$ & $6.1 \mathrm{a}$ & $6.2 \mathrm{a}$ & $6.2 \mathrm{a}$ & $6.3 \mathrm{a}$ & $5.6 \mathrm{~b}$ \\
\hline $2005 / 06$ & $6.2 \mathrm{a}$ & $6.3 \mathrm{a}$ & $5.8 \mathrm{ab}$ & $6.1 \mathrm{a}$ & $5.7 \mathrm{ab}$ & $5.5 \mathrm{~b}$ \\
\hline \multirow[t]{2}{*}{$2006 / 07$} & $6.2 \mathrm{a}$ & $6.1 \mathrm{a}$ & $5.4 b^{(5)}$ & $6.4 \mathrm{a}$ & $5.2 \mathrm{~b}^{(5)}$ & $5.8 \mathrm{ab}$ \\
\hline & \multicolumn{6}{|c|}{$\mathrm{pH}$} \\
\hline $2003 / 04$ & $3.40 \mathrm{a}$ & $3.41 \mathrm{a}$ & $3.44 \mathrm{a}$ & $3.46 \mathrm{a}$ & $3.45 \mathrm{a}$ & $3.45 \mathrm{a}^{(4)}$ \\
\hline $2004 / 05$ & $3.34 \mathrm{a}$ & $3.34 \mathrm{a}$ & $3.32 \mathrm{a}$ & $3.34 \mathrm{a}$ & $3.30 \mathrm{a}$ & $3.31 \mathrm{a}$ \\
\hline $2005 / 06$ & $3.23 \mathrm{a}$ & $3.32 \mathrm{a}$ & $3.33 \mathrm{a}$ & $3.33 \mathrm{a}$ & $3.30 \mathrm{a}$ & $3.33 \mathrm{a}$ \\
\hline \multirow[t]{2}{*}{$2006 / 07$} & $3.08 \mathrm{c}$ & $3.12 \mathrm{c}$ & $3.50 \mathrm{a}^{(5)}$ & $3.07 \mathrm{c}$ & $3.52 \mathrm{a}^{(5)}$ & $3.35 \mathrm{~b}$ \\
\hline & \multicolumn{6}{|c|}{ Wine colour $(\%)$} \\
\hline $2003 / 04^{(6)}$ & $80 \pm 12$ & $83 \pm 13$ & $74 \pm 15$ & $85 \pm 9$ & $75 \pm 16$ & $79 \pm 14^{(4)}$ \\
\hline $2004 / 05$ & $82 \mathrm{a}$ & $77 \mathrm{ab}$ & $66 \mathrm{~b}$ & $80 \mathrm{a}$ & $71 \mathrm{ab}$ & $65 \mathrm{~b}$ \\
\hline $2005 / 06$ & $78 \mathrm{a}$ & $74 \mathrm{a}$ & $73 \mathrm{a}$ & $76 \mathrm{a}$ & $77 \mathrm{a}$ & $62 \mathrm{~b}$ \\
\hline \multirow[t]{2}{*}{$2006 / 07$} & $81 \mathrm{a}$ & $79 \mathrm{ab}$ & $70 b^{(5)}$ & $79 \mathrm{ab}$ & $58 \mathrm{c}^{(5)}$ & $72 \mathrm{ab}$ \\
\hline & \multicolumn{6}{|c|}{ Berry character $(\%)$} \\
\hline $2003 / 04^{(6)}$ & $45 \pm 26$ & $60 \pm 19$ & $52 \pm 19$ & $68 \pm 20$ & $47 \pm 22$ & $57 \pm 25^{(4)}$ \\
\hline $2004 / 05$ & $52 \mathrm{abc}$ & $56 \mathrm{ab}$ & $50 \mathrm{abc}$ & $58 \mathrm{a}$ & $43 \mathrm{c}$ & $46 \mathrm{bc}$ \\
\hline $2005 / 06$ & $55 \mathrm{ab}$ & $56 a b$ & $52 \mathrm{ab}$ & $60 \mathrm{a}$ & $56 \mathrm{ab}$ & $49 \mathrm{~b}$ \\
\hline \multirow[t]{2}{*}{$2006 / 07$} & $60 \mathrm{a}$ & $58 \mathrm{a}$ & $41 \mathrm{c}^{(5)}$ & $57 \mathrm{ab}$ & $47 \mathrm{bc}^{(5)}$ & $52 \mathrm{ab}$ \\
\hline & \multicolumn{6}{|c|}{ Overall wine quality (\%) } \\
\hline $2003 / 04^{(6)}$ & $55 \pm 18$ & $59 \pm 14$ & $54 \pm 13$ & $66 \pm 22$ & $47 \pm 11$ & $59 \pm 15^{(4)}$ \\
\hline $2004 / 05$ & $59 \mathrm{a}$ & $58 \mathrm{a}$ & $48 \mathrm{~b}$ & $61 \mathrm{a}$ & $48 \mathrm{~b}$ & $46 \mathrm{~b}$ \\
\hline $2005 / 06$ & $57 \mathrm{ab}$ & $56 \mathrm{ab}$ & $52 \mathrm{~b}$ & $64 \mathrm{a}$ & $52 \mathrm{~b}$ & $43 \mathrm{c}$ \\
\hline $2006 / 07$ & $58 \mathrm{a}$ & $58 \mathrm{a}$ & $46 b^{(5)}$ & $58 \mathrm{a}$ & $46 b^{(5)}$ & $51 \mathrm{ab}$ \\
\hline
\end{tabular}

(1) Irrigations at pea size, véraison and post-harvest.

(2) Irrigations at pea size, mid-December, véraison, end January and post-harvest.

(3) Values followed by the same letter within a row do not differ significantly $(p \leq 0.05)$.

(4) In 2003/04, the T6 grapevines received only low frequency irrigation in alternating work rows.

(5) In 2006/07, the T3 and T5 grapevines were irrigated at the same frequency as the PRD ones.

(6) Mean sensorial score by tasting panel \pm standard deviation. 
compared to non-irrigated conditions and three irrigations in the 2005/06 season, whereas slightly wetter conditions (T3 and T5) only tended to reduce TTA. The stronger vegetative growth induced by the PRD strategy (Table 3) probably decreased TTA via the effect of more shaded leaves (Iland, 1989) compared to the less vigorous growth obtained with some of the other strategies. In previous studies, PRD lowered the juice TTA compared to intensively irrigated control treatments (Santos et al., 2005; Bindon et al., 2008). In these studies, PRD increased sunlight penetration in the bunch zone, which probably lowered TTA more than in the denser canopies of the control treatments via the effect of increased berry exposure (Iland, 1989). Where PRD-treated grapevines received the same volume of irrigation as the control treatment and cane masses were comparable, PRD did not affect juice TTA compared to the control (De la Hera et al., 2007). In the 2006/07 season, the high frequency irrigation (T3 and T5), which induced mild grapevine water constraints (Myburgh, 2011) and delayed berry maturation, reduced juice TTA compared to drier soil conditions (Table 5). In this particular season the PRD strategy only tended to reduce TTA compared to non-irrigated conditions (T1) and three irrigations (T2 and T4).

Except where T3 and T5 grapevines were irrigated two times per week in the 2006/07 season, non-irrigated conditions and the different irrigation strategies did not cause excessively high juice $\mathrm{pH}$, i.e. $>3.5$, in any of the four seasons (Table 5). During the first three seasons the different irrigation strategies had no effect on juice $\mathrm{pH}$ compared to non-irrigated conditions. Previous studies have shown that PRD had no effect on juice $\mathrm{pH}$ compared to intensively irrigated grapevines (Loveys et al., 2000; Du Toit et al., 2003; Dos Santos et al., 2003; Santos et al., 2005), or where PRD and control grapevines received the same irrigation volumes (Du Toit et al., 2003; De la Hera et al., 2007). In contrast, higher juice $\mathrm{pH}$ was obtained with the PRD strategy than with intensive drip irrigation (Dry et al., 1996; Bindon et al., 2008). In the 2006/07 season the lower TTA caused by delayed ripening in the case of mild (T3 and T5) and moderate water constraints (T6) compared to severe water constraints (T1, T2 and T4) contributed to the high juice $\mathrm{pH}$ (Table 5). This effect was probably induced via the effect of more leaf shading (Iland, 1989). Irrigation applied in the work rows had no effect on juice TTA and $\mathrm{pH}$ compared to irrigation in the grapevine rows during any of the seasons (Table 5).

\section{Sensorial wine characteristics}

Given the constraints of small-scale winemaking and sensorial scoring, an evaluation of the sensorial wine characteristics merely served as an indication of the potential of a specific irrigation strategy to improve wine quality/style. The nonirrigated conditions and different irrigation strategies had no effect on the fresh vegetative, spicy or dried-fruit aromas, or on the acidity, fullness and astringency in the wines (data not shown). In the 2003/04 season, wines produced from grapevines where three irrigations in the work rows (T4) induced strong water constraints tended to have more intense colour and prominent berry aroma, viz. blackberry, raspberry, strawberry and blackcurrant (Table 5). These trends probably enhanced the tendency towards higher overall wine quality compared to nonirrigated conditions and the other irrigation strategies. Although non-irrigated conditions and three irrigations in the work rows (T4) induced only moderate water constraints in the 2004/05 season (Myburgh, 2011), better wine colour was obtained in comparison to that from mild water constraints induced by five irrigations in the grapevine rows (T3) and the PRD strategy (Table 5). Three irrigations in the work rows also enhanced berry character compared to five irrigations in the work rows (T5) and the PRD strategy. Drier conditions (T1, T2 and T4) produced better overall wine quality compared to five irrigations (T3 and T5) and the PRD strategy. In the 2005/06 season, moderate water constraints in the PRD grapevines reduced wine colour, berry character and overall quality compared to grapevines in which three irrigations in the work rows induced strong water constraints (T4). In this particular season, strong water constraints (T3 and T5) also produced wines of inferior overall quality compared to severe water constraints (T4). When the T3 and T5 grapevines were irrigated at the same frequency as the PRD ones in the 2006/07 season, the mild water constraints lowered wine colour, berry aroma and overall quality compared to non-irrigated conditions, i.e. severe water constraints (Table 5). Severe water constraints induced by three irrigations (T2 and T4) also produced wines that were superior in colour, berry character and overall quality compared to the wines produced from grapevines that had experienced mild water constraints resulting from high frequency irrigation in the work rows (T5).

\section{CONCLUSIONS}

In addition to the seasonal variance in yield components, yield variation was positively related to the irrigation volumes applied plus rainfall from bud break in September until harvest in February/March. Under the given conditions, yield seemed to have reached a maximum when irrigation plus rainfall amounted to $c a$. $400 \mathrm{~mm}$ during the growing period. Where low frequency irrigation and the PRD strategy reduced grapevine water constraints, yields were higher compared to non-irrigated grapevines that experienced strong to severe water constraints. Although three irrigations increased yields compared to non-irrigated conditions in some seasons, it did not have any negative effects on sensorial wine quality characteristics. It must be noted that, although the non-irrigated grapevines consistently produced the smallest berries, they did not necessarily produce wines superior in colour, berry aroma or overall quality compared to wines from grapevines that received three irrigations in any of the four seasons. Five irrigations consistently increased yields, but the lower levels of water constraints produced wines of inferior overall quality compared to those from non-irrigated conditions. Similarly, irrigation according to the PRD strategy reduced wine quality, particularly when irrigations between switches were applied at a high irrigation frequency, viz. twice a week. Based on the criterion that IWP is only improved when more grapes are produced with existing water resources or when existing yields are maintained with less water, the PRD strategy only improved IWP compared to conventional drip irrigation when unnecessary high volumes of water were applied. If high wine quality is the primary objective, Merlot grapes can be produced without irrigation under the given conditions. However, if yield is more important, at least $400 \mathrm{~mm}$ of irrigation per season would be necessary to maintain acceptable yields. For 
a balance between yield and wine quality, Merlot should only be irrigated at pea size and véraison under the given conditions. In sandy soils, Merlot might require more frequent irrigation. The drier strategies can only be justified if higher grape and/ or wine prices will compensate for possible yield reductions. Subsurface irrigation applied in the work rows did not have any positive effects on vegetative growth and yield components. Furthermore, dripper clogging caused by root penetration could reduce the lifespan of subsurface dripper lines. Hence, this practice cannot be recommended in commercial vineyards.

\section{LITERATURE CITED}

Bindon, K., Dry, P.R. \& Loveys, B., 2008. Influence of partial root zone drying on the composition and accumulation of anthocyanins in grape berries (Vitis vinifera cv. Cabernet Sauvignon). Aust. J. Grape Wine Res. 14, 91-103.

Böhm, W., 1979. Methods of studying root systems. Springer-Verlag, Berlin.

Boshoff, C.J., 2010. A study of the interaction between grapevine vigour and water status for Vitis vinifera L. $c v$ Merlot noir in Stellenbosch. Thesis, Stellenbosch University, Private Bag X1, Matieland 7602, South Africa.

De la Hera, M.L., Romero, P. Gomez-Plaza, E. \& Martinez, A., 2007. Is partial root-zone drying an effective irrigation technique to improve water use efficiency and fruit quality in field-grown wine grapes under semiarid conditions? Agric. Water Manage. 87, 261-274.

Dos Santos, T.P., Lopes, C.M., Rodrigues, M.L., De Souza, C.R., Maroco, J.P., Pereira, J.S., Silva, J.R. \& Chaves, M.M., 2003. Partial rootzone drying: effects on growth and fruit quality of field-grown grapevines (Vitis vinifera). Func. Plant Biol. 30, 663-671.

Dry, P., Loveys, B., Botting, D. \& Düring, H., 1996. Effects of partial root-zone drying on grapevine vigour, yield, composition of fruit and use of water. In: Stockley, C.S., Sas, A.N., Johnstone, R.S. \& Lee, T.H. (eds). Proc. $9^{\text {th }}$ Aust. Wine Ind. Tech. Conf., July 1995, Adelaide, Australia. pp. 128 - 131.

Du Toit, P.G., Dry, P.R. \& Loveys, B., 2003. A preliminary investigation on partial rootzone drying (PRD) effects on grapevine performance, nitrogen assimilation and berry composition. S. Afr. J. Enol. Vitic. 24, 43-54.

Hunter, J.J., 1998. Plant spacing implications for grafted grapevine I. Soil characteristics, root growth, dry matter partitioning and soil utilisation. S. Afr. J. Enol. Vitic. 19, 25-34

Iland, P., 1989. Grape berry composition - the influence of environmental and viticultural factors. Part 2 - Solar radiation. Aust. Grapegrow. Winemaker April 1989, 74-76

Lategan, E.L. \& Howell, C.L., 2010a. The partial rootzone drying (PRD) of Merlot in the Breede River Valley (Part 1): Irrigation volumes, plant water stress and vigour. Wynboer Technical Yearbook 2010, 19-21.

Lategan, E.L. \& Howell, C.L., 2010b. The partial rootzone drying (PRD) of Merlot in the Breede River Valley (Part 2): Production, water use efficiency and wine quality. Wynboer Technical Yearbook 2010, 22-24.

Le Roux, E.G., 1974. A climate classification for the South Western Cape viticultural areas (in Afrikaans). Thesis, Stellenbosch University, Private Bag X1, 7602 Matieland (Stellenbosch), South Africa.

Ley, T.W., 1994. Irrigation system evaluation and improvement. In: Williams, K.M. \& Ley, T.W. (eds). Tree fruit irrigation: a comprehensive manual of deciduous tree fruit irrigation needs. Good Fruit Grower, Yakima, Washington. pp. $203-221$.

Loveys, B.R., Dry, P.R., Stoll, M. \& McCarthy, M.G., 2000. Using plant physiology to improve the water use efficiency of horticultural crops. Acta Hort. 537, 187-197.
Marsal, J., Mata, M., Del Campo, J, Arbones, A., Vallverdú, X. \& Olivo, N., 2008. Evaluation of partial root-zone drying for potential field use as a deficit irrigation technique in commercial vineyards according to two different pipe layouts. Irrig. Sci. 26, 347-356.

Myburgh, P.A., 1996. Response of Vitis vinifera L. cv. Barlinka/Ramsey to soil water depletion levels with particular reference to trunk growth parameters. S. Afr. J. Enol. Vitic. 17, 3-14

Myburgh, P.A., 1998. Water consumption of South African vineyards: a modelling approach based on the quantified combined effects of selected viticultural, soil and meteorological parameters. Thesis, Stellenbosch University, Private Bag X1, 7602 Matieland (Stellenbosch), South Africa.

Myburgh, P.A., 2003. Possible flood irrigation technologies to reduce water use of Sultanina grapevines in a hot, arid climate. S. Afr. J. Plant Soil 20, 1-8

Myburgh, P.A., 2005. Water status, vegetative growth and yield responses of Vitis vinifera L. cvs. Sauvignon blanc and Chenin blanc to timing of irrigation during berry ripening in the Coastal region of South Africa. S. Afr. J. Enol Vitic. 27, 1-7.

Myburgh, P.A., 2007a. An investigation into possible water savings using sub-surface irrigation (Part I) - Irrigation quantities, wetting patterns and root distribution. Wynboer Technical Yearbook 2007/08, 33-37.

Myburgh, P.A., 2007b. An investigation into possible water savings using sub-surface irrigation (Part II) - Plant water stress, growth, yield and quality. Wynboer Technical Yearbook 2007/08, 38-42.

Myburgh, P.A., 2007c. The effect of irrigation on growth, yield, wine quality and evapotranspiration of Colombar in the Lower Orange River Region. Wynboer Technical Yearbook 2007/08, 59-62.

Myburgh, P.A., 2011. Response of Vitis vinifera L. cv. Merlot to low frequency drip irrigation and partial root zone drying in the Western Cape coastal regionPart I. Soil and Plant Water Status. S. Afr. J. Enol. Vitic. 32, 89-103.

Myburgh, P.A. \& Howell, C.L., 2007. Evapotranspiration of Vitis vinifera L. cvs Sunred Seedless and Muscat Supreme in response to soil water depletion and irrigation cutoff during berry ripening. S. Afr. J. Plant Soil 24, 209-213.

Sadras, V.O., 2009. Does partial root-zone drying improve irrigation water productivity in the field? A meta-analysis. Irrig. Sci. 27, 183-190.

Santos, T.P., Lopes, C.M., Rodrigues, M.L., De Sousa, C.R., Ricardo-Da-Silva, J.M., Maroco, J.P., Pereira, J.S. \& Chaves, M.M., 2005. Effects of partial rootzone drying irrigation on cluster microclimate and fruit composition of fieldgrown Castelão grapevines. Vitis 44, 117-125.

Southey, J.M. \& Archer, E., 1988. The effect of rootstock cultivar on root distribution and density. In: Van Zyl, J.L. (ed). The grapevine root and its environment. Tech. Comm., Dept. Agric. Water Supply, Private Bag X144, Pretoria 0001. pp. 57-73.

Swanepoel, J.J., Hunter, J.J. \& Archer, E., 1990. The effect of trellis systems on the performance of Vitis vinifera L. cvs Sultanina and Chenel in the Lower Orange River region. S. Afr. J. Enol. Vitic. 11, 59-66.

Van Zyl, J.L., 1984. Response of Colombar grapevines to irrigation as regards quality aspects and growth. S. Afr. J. Enol. Vitic. 5, 19-28.

Van Zyl, J.L., 1988. Response of grapevine roots soil water regimes and irrigation systems. In: Van Zyl, J.L. (ed). The grapevine root and its environment. Tech. Comm., Dept. Agric. Water Supply, P/Bag X144, Pretoria 0001. pp. 74 - 87.

Van Zyl, J.L. \& Van Huyssteen, L., 1980. Comparative studies on wine grapes on different trellis systems: I. Consumptive water use. S. Afr. J. Enol. Vitic. 1, $7-14$

Van Zyl, J.L. \& Van Huyssteen, L., 1987. Root pruning. Decid. Fruit Grow. January 1987, 20-25. 
Van Zyl, J.L. \& Weber, H.W., 1981. The effect of various supplementary irrigation treatments on plant and soil moisture relationships in a vineyard (Vitis Vinifera var. Chenin blanc). S. Afr. J. Enol. Vitic. 2, 83-99.
Winkler, A.J., 1962. General viticulture. University of California Press, Los Angeles. 